\title{
PEMBELAJARAN KANJI DI KELAS N4 KEPERAWATAN LPK LPJ (Lembaga Pelatihan Bahasa Jepang) BALI
}

\author{
N.N.P. Noviyanthi ${ }^{1}$, I.W. Sadyana ${ }^{2}$,K.E.K Adnyani ${ }^{3}$ \\ ${ }^{123}$ Jurusan Bahasa Asing, Universitas Pendidikan Ganesha, Singaraja \\ e-mail: nyoman.putri.noviyanthi@undiksha.ac.id, wayan.sadyana@undiksha.ac.id, \\ krishna.adnyani@undiksha.ac.id
}

\begin{abstract}
Abstrak
Penelitian ini bertujuan untuk mendeskripsikan (1) Strategi pembelajaran Kanji yang digunakan oleh guru di kelas N4 Keperawatan LPK LPJ (Lembaga Pelatihan Bahasa Jepang) Bali (2) Faktorfaktor pemilihan strategi pembelajaran Kanji oleh guru di kelas N4 Keperawatan LPK LPJ Bali, dan (3) Hambatan dalam pembelajaran Kanji yang dihadapi oleh guru di kelas N4 Keperawatan LPK LPJ Bali. Subjek penelitian ini adalah guru pengajar Kanji di kelas N4 Keperawatan LPK LPJ Bali. Pengumpulan data dilakukan dengan metode observasi, wawancara, dan dokumentasi, kemudian dianalisis dengan metode deskriptif kualitatif. Hasil penelitian menunjukkan bahwa (1) Strategi pembelajaran Kanji yang digunakan oleh guru di kelas N4 Keperawatan LPK LPJ Bali, yaitu strategi drill, ekspositori, permainan dan pemberian tugas; (2) Faktor-faktor pemilihan strategi pembelajaran, yaitu pertama karakteristik peserta didik yang berusia 19-29 tahun dan memiliki latar belakang pendidikan sebagai perawat. Sehingga peserta didik merupakan pembelajar pemula. Kedua, kompentensi dasar yang diharapkan, yaitu kemampuan menguasai Kanji. Ketiga, waktu yang tersedia, yaitu hanya 3 bulan. Hambatan dalam pembelajran, yaitu hambatan manusiawi, institusional dan instruksional.
\end{abstract}

Kata kunci: kanji, profil, strategi pembelajaran

\begin{abstract}
要旨
本研究の目的は、(1)LPJBaliの送り出し機関のN4看護クラスにおける漢字科指導講師が使用される学 習法、(2)当送り出し機関の指導講師が使用される学習法の要因、(3)漢字科を担当する指導講師が、授 業の際に直面する障害をを明示することである。研究の対象は、当送り出し機関の漢字科指導講師で ある。データは、授業観察、インタビューおよび画像写真により収集し、それを定性的記述法により 分析した。その結果は、(1)当送り出しにおける漢字科指導講師が使用される学習法は、ドリル、直接 法、ゲーム、タスクである。(2)学習法を選択する要因は以下通りである。a)学習者の特徵は年齢が19 ２9歳及び看護師としての学歴があります。つまり、その生徒達は初心者学習者である。b)基礎学力 は漢字能力が期待されます。c)時間制は3ヶ月に限るです。(3)漢字科指導講師の障害は人道的及び制 度上及び指示詞である。
\end{abstract}

キーワード : 漢字、紹介、学習法

\section{Pendahuluan}

LPK (Lembaga Pelatihan Kerja) merupakan lembaga Pendidikan non formal yang diselenggarakan bagi masyarakat untuk memberikan pengetahuan dan keterampilan. Lembaga ini mempunyai peranan penting dalam meningkatkan kualitas SDM (Sumber Daya Manusia). Terdapat berbagai jenis LPK, salah satunya, yaitu LPK yang memberikan pembelajaran bahasa asing, seperti bahasa Jepang. Berdasarkan data Japan Foundation tahun 2015, jumlah pembelajar bahasa Jepang di Indonesia meningkat hingga $22,2 \%$. Hal tersebut karena banyak tersedia lapangan pekerjaan yang menuntut kemampuan bahasa Jepang baik di dalam maupun luar negeri, khususnya di Jepang. Sehingga, banyak masyarakat tertarik untuk mempelajari bahasa Jepang.

LPK LPJ Bali merupakan salah satu LPK yang mengadakan pembelajaran bahasa Jepang. LPJ merupakan singkatan dari Lembaga Pelatihan bahasa Jepang. LPK LPJ Bali mencetak calon tenaga kerja magang ke Jepang. LPK ini bekerja sama dengan beberapa koperasi penyalur tenaga kerja, di antaranya koperasi di daerah Chiba, Saitama, Tokyo, Nagoya, Ehime, Gifu, Kumamoto, Hiroshima, Miyazaki, Kagoshima dan Fukuoka. Tenaga kerja asing yang sangat dibutuhkan, yaitu perawat lansia (kaigoshi). Mengingat, jumlah 
perawat lansia yang kurang memadai di Jepang. Oleh karena itu, banyak siswa lulusan SMA/SMK, diploma dan Sarjana Keperawatan tertarik untuk bekerja ke Jepang.

Pada tahun 2018, jumlah siswa di LPK LPJ Bali, yaitu 117 orang. Dengan pembagian 66 orang calon tenaga kerja umum dan 51 orang calon tenaga kerja perawat lansia. Jumlah tersebut dapat dikatakan banyak apabila dibandingkan dengan jumlah siswa di LPK lainnya. Kebijakan bebas biaya belajar bagi perawat menjadi salah satu faktor meningkatnya minat siswa untuk bekerja ke Jepang melalui LPK ini. Hal tersebut karena biaya sudah ditanggung oleh pihak Jepang.

LPK LPJ Bali konsisten dalam menetapkan target pembelajaran. Khusus bagi siswa perawat wajib untuk lulus tes JLPT (Japanese Language Proficiency Test) yang dalam bahasa Jepang, yaitu Nihongo Kentei shiken (日本語検定試験) level 4 (empat). Namun, siswa dapat mengikuti tes kemampuan bahasa Jepang yang lain, seperti NAT-Test dan JTest. Mengingat, JLPT hanya dilaksanakan setahun sekali di Bali. Berbeda halnya dengan NAT-Test yang diselenggarakan dua bulan sekali, dan J-Test yang diselenggarakan tiga bulan sekali. Oleh karena itu, pihak Jepang memberikan toleransi kepada siswa perawat untuk lulus NAT-Test dan J-Test yang juga diakui secara Internasional.

Terdapat landasan kuat mengenai syarat wajib lulus N4 bagi siswa perawat. Pertama, bahasa Jepang level 4 banyak digunakan dalam kehidupan sehari-hari di Jepang, terutama mengenai aturan dan larangan umum. Kedua, sebagai standar kemampuan minimal, bahasa ini sering digunakan dalam lingkungan kerja, misalnya dengan rekan kerja. Ketiga, bagi perawat lansia, kemampuan pada level tersebut sangat dibutuhkan untuk dapat berkomunikasi khususnya dengan para lansia. Sehingga mereka dapat melakukan pelayanan secara optimal. Untuk dapat berkomunikasi dalam bahasa Jepang, para perawat harus mempunyai pengetahuan mengenai kosa kata, tata bahasa serta memiliki kemampuan mendengarkan dalam bahasa Jepang.

Hal tersebut berkaitan dengan soal pada tes kemampuan bahasa Jepang. Terdapat tiga jenis soal pada tes tersebut, yaitu kosa kata (moji gol), tata bahasa (bunpou), membaca (dokkal), serta mendengarkan (choukai). Namun, tantangan pertama yang dihadapi siswa dalam menjawab soal JLPT, NAT-Test, dan J-Test, yaitu membaca huruf Jepang khususnya Kanji. Bagi siswa perawat, Kanji merupakan komponen bahasa jepang yang sulit. Hal tersebut disebabkan karna siswa perawat belum pernah mempelajari Kanji. Herniawati (2014), mengungkapkan kesulitan yang sering dihadapi siswa dalam menjawab tes kemampuan bahasa Jepang level tinggi disebabkan karena tidak mampu membaca dan memahami Kanji yang muncul pada soal tersebut. Hal ini berkaitan dengan tes level N4 yang juga menggunakan Kanji. Tidak semua Kanji yang muncul dalam soal berisikan cara baca (furigana). Sehingga, siswa dituntut untuk mengetahui dan memahami Kanji yang muncul saat menjawab soal.

Dalam wawancara tanggal 1 Agustus 2019, Ketua Instruktur di LPK LPJ Bali menegaskan bahwa mata pelajaran yang lebih ditekankan kepada siswa di kelas N4 Keperawatan, yaitu Kanji. Pembelajaran ini sangat penting agar siswa mampu membaca dan memahami Kanji yang muncul dalam tes. Selain itu, sebagai persiapan agar siswa mampu menyelesaikan hal-hal yang berkaitan dengan adiministrasi ketika bekerja di Jepang. Oleh karena itu, kompetensi yang dituntut tidak hanya membaca melainkan juga menulis Kanji.

Buku yang digunakan sebagai bahan ajar, yaitu buku Basic Kanji Book 2, dan buku kumpulan soal Moji Goi. Siswa diberikan materi Basic Kanji Book 2 terlebih dahulu lalu diberikan latihan soal-soal Moji Goi. Materi dalam buku tersebut cukup banyak, yakni 22 bab, 248 kanji. Terdapat kosa kata yang muncul pada setiap kanji, yakni total sekitar 950 kota kata. Karena kerterbatasan waktu, materi tersebut dibatasi oleh guru mengikuti hasil rapat dengan tim pengajar di LPK LPJ Bali.

Materi Basic Kanji Book 2 diajarkan mulai bab 23 sampai bab 34, sehingga total terdapat 12 bab. Dalam 12 bab terdapat 137 Kanji, dan 456 kosa kata. Hal tersebut menyesuaikan dengan alokasi waktu belajar di kelas N4, yaitu selama 3 bulan. Selama 3 bulan terdapat 12 kali pertemuan, yakni seminggu sekali. Sedangkan, dalam satu kali pertemuan terdapat alokasi waktu 3-4 jam. Dalam satu kali pertemuan tersebut dibahas 1 bab Kanji. 
Meskipun waktu yang dapat dikatakan singkat serta materi Kanji yang sulit, siswa mampu mencapai target pembelajaran dengan rata-rata nilai tes 81,5 . Selain itu banyak siswa juga mampu lulus NAT-Test maupun $J$-Test. Hal tersebut tentu didukung oleh strategi pembelajaran Kanji yang digunakan oleh guru. Target pembelajaran dapat tercapai apabila guru dapat menggunakan strategi yang tepat. Oleh Karena itu, penelitian mengenai profil strategi pembelajaran Kanji di kelas N4 Keperawatan penting untuk dilakukan.

Penelitian mengenai pembelajaran Kanji tidak hanya penting melainkan juga menarik untuk diteliti. Hal tersebut melihat dari penelitian sebelumnya yang dilakukan oleh Rose (2013) yang membahas mengenai penggunaan strategi mnemonik dalam pembelajaran Kanji oleh pembelajar bahasa asing. Penelitian ini menggunakan metode kualitatif. Hasil dari penelitian ini, yaitu strategi mnemonik berguna dalam mengingat Kanji dan komponen Kanji karena penerapannya berupa pembelajaran bermakna.. Penelitian ini berfokus pada penggunaan strategi mnemonik namun tidak membahas mengenai faktor pemilihan strategi tersebut serta hambatan yang dihadapi dalam pembelajaran sehingga strategi tersebut sukses digunakan dalam pembelajaran Kanji.

Berdasarkan latar belakan tersebut, dapat dirumuskan permasalahan sebagai berikut (1) Bagaimanakah strategi pembelajaran Kanji yang digunakan oleh guru di kelas N4 Keperawatan LPK LPJ Bali ?(2) Bagaimanakah faktor-faktor pemilihan strategi pembelajaran Kanji di kelas N4 Keperawatan LPK LPJ Bali ? (3) Bagaimanakan hambatan pembelajaran Kanji yang dihadapi guru di kelas N4 Keperawatan LPK LPJ Bali?

Berdasarkan rumusan masalah tersebut, dapat dirumuskan tujuan sebagai berikut (1) Mendeskripsikan strategi pembelajaran Kanji yang digunakan oleh guru di kelas N4 Keperawatan LPK LPJ Bali; (2) Mendeskripsikan faktor-faktor pemilihan strategi pembelajaran Kanji di kelas N4 Keperawatan LPK LPJ Bali; (3) Mendeskripsikan hambatan pembelajaran Kanji yang dihadapi guru di kelas N4 Keperawatan LPK LPJ Bali.

Terdapat beberapa teori yang digunakan dalam penelitian ini, yaitu (1) Pembelajaran Kanji; (2) Metode Pembelajaran Bahasa Asing; (3) Strategi Pembelajaran Bahasa Asing; (4) Faktor-faktor Pemilihan Strategi Pembelajaran; (5) Hambatan dalam Pembelajaran.

Pembelajaran Kanji, yaitu pembelajaran mengenai Kanji sebagai huruf yang memiliki karakteristik tersendiri dan melambangkan makna tertentu.

Metode pembelajaran bahasa asing digunakan saat berinteraksi dengan siswa dalam pembelajaran. Beberapa metode pembelajaran bahasa, yaitu (a) Metode terjemahan, yaitu metode mengenai terjemahan tata bahasa (Benati , 2018); (b) Direct Method atau metode langsung, yaitu yang mana bahasa yang dipelajari melalui asosiasi langsung mengenai kosa kata maupun frasa dengan objek dalam bahasa target (Tarigan, 2011); (c) Metode audiolingual, yaitu metode yang berkaitan dengan ear training (latihan mendengar) dan speak training (latihan berbicara) (Yani, 2016: 12); (d) Communicative Language Teaching $(C L T)$, yaitu metode yang menekankan terjadinya komunikasi menggunakan bahasa target di dalam kelas dengan tetap mementingkan ketepatan dari bahasa target (Febrianti, 2017); (e) TPR (Total Physical Respons), yaitu metode yang disusun pada koordinasi perintah (command), ucapan (speech) dan gerak (action) (Samad dan Todore, 2015).

Strategi pembelajaran bahasa asing merupakan suatu perencanaan yang berisi tentang rangkaian kegiatan yang didesain untuk mencapai tujuan pembelajaran. Adapun beberapa strategi pembelajaran yaitu, (a) Diskusi, yaitu strategi belajar mengajar yang fleksibel yang dapat diadaptasikan agar sesuai dengan topik pada level tertentu dari tingkat dasar sampai tingkat lanjut (Sanjaya, 2016: 154); (b) Role play, yaitu suatu aktivitas yang terbentuk dari situasi, karakter dan bahasa (Gracia, 2018); (c) Strategi lagu dan permainan, yaitu strategi yang digunakan untuk meningkatkan minat belajar siswa serta melatih siswa dalam menggunakan kosa kata secara komunikatif dan nyata (Padmadewi, 2012: 150); (d) Ceramah, yaitu cara tradisional dalam menyampaikan keterangan, informasi atau uraian tentang suatu pokok persoalan, (Roestiyah, 2012: 136); (e) Dril, yaitu cara mengajar dimana siswa diberikan latihan agar memiliki suatu keterampilan (Roestiyah 2012: 125); (f) strategi tanya jawab, yaitu strategi yang digunakan guru untuk mengetahui sejauh mana pemahaman siswa terhadap pelajaran yang diberikan memberikan dengan memberikan pertanyaan. Strategi ini dapat bersifat dua arah (Hamdayama, 2016: ); (g) Strategi 
pemberian tugas, yaitu bentuk pengayaan dari materi yang telah diajarkan (Roestiyah, 2012: 132); (h) Information gap activities adalah aktivitas yang mana siswa melakukan kegiatan secara berpasangan. Salah satu siswa memiliki informasi yang berbeda dengan siswa yang lain sehingga mereka harus bertukar informasi (Kayi, 2006); (i) Strategi pembelajaran ekspositori adalah strategi pembelajaran yang memadukan strategi ceramah, tanya jawab dan peragaan demonstrasi (Sanjaya, 2016).

Pemilihan strategi pembelajaran dapat dilakukan oleh siswa maupun guru (Sunendar dan Iskandarwassid, 2015: 168). Adapun faktor pemilihan strategi pembelajaran menurut Sunendar dan Iskandarwassid (2015), yaitu (1) Karakteristik peserta didik, diantaranya kematangan mental dan kecakapan intelektual, kondisi fisik dan kecakapan psikomotor, umur; dan jenis kelamin; (2) Kompetensi dasar yang diharapkan, yaitu pernyataan memadai tentang pengetahuan, keterampilan, sikap yang direfleksikan dalam kebiasaan berpikir dan bertindak setelah peserta didik menyelesaikan aspek pelajaran tertentu; (3) Bahan ajar, yaitu seperangkat informasi yang harus diserap peserta didik dalam pembelajaran; (4) Waktu yang tersedia, yaitu kurun waktu untuk mencapai komptensi dasar misalnya dalam watu 3 bulan, enam bulan, maupun satu tahun. Guru kemudian mengembangkan bahan ajar untuk dapat mencapai kompetensi tersebut; (5) Sarana dan prasarana pembelajaran. Sarana belajar adalah segala sesuatu yang langsung digunakan peserta didik. Sedangkan, prasarana adalah segala sesuatu yang merupakan penunjang proses pembelajaran. (6) Kemampuan pengajar dalam memilih strategi pembelajaran sangat penting agar kompetensi yang diharapkan dapat tercapai. Guru harus mampu memilih strategi yang cocok dengan pembelajaran.

Hambatan dalam pembelajaran dapat bersumber dari dalam maupun luar. Faktor tersebut, diantaranya faktor manusiawi, institusional, dan intruksional. Manusiawi,yaitu berkaitan dengan keterampilan guru dan kemampuan siswa. Institusional berkaitan dengan sarana belajar, yakni media dan alat peraga. Sedangkan, instruksional berkaitan dengan prasarana yakni fasilitas kelas, labolatorium dan lain-lain (Hamalik, 2002).

Teori-teori yang sudah dipaparkan di atas digunakan sebagai bahan perbandingan untuk dapat mendeskripsikan strategi pembelajaran Kanji yang digunakan oleh guru, faktor pemilihan strategi pembelajaran Kanji oleh guru, dan hambatan dalam pembelajaran Kanji yang diharapi oleh guru di kelas N4 Keperawatan LPK LPJ Bali.

\section{Metode}

Penelitian ini merupakan penelitian deskriptif kualitatif. Data dalam penelitian ini diperoleh melalui tiga cara, yaitu observasi, wawancara, dan dokumentasi. Hasil dari penelitian ini hanya mendeskripsikan atau mengkontruksikan hasil observasi dan wawancara terhadap subjek penelitian sehingga dapat memberikan gambaran yang jelas mengenai strategi pembelajaran, faktor-faktor pemilihan strategi pembelajaran, serta hambatan dalam pembelajaran Kanji yang dihadapi oleh guru di kelas N4 Keperawatan LPK LPJ Bali. Selanjutnya, pengumpulan data melalui dokumentasi untuk mendapatkan data pendukung.

\section{Hasil dan Pembahasan}

Data dalam penelitian ini diperoleh melalui observasi, wawancara, dan dokumentasi. Observasi dilakukan sebanyak 7 kali, yaitu 3 kali di kelas N4 A dan 4 kali di kelas N4 B. Wawancara yang dilakukan adalah wawancara terstruktur untuk mengetahui lebih mendalam mengenai strategi pembelajaran kanji, faktor-faktor pemilihan strategi pembelajaran, dan hambatan dalam pembelajaran kanji yang dihadapi oleh guru di kelas N4 Keperawatan LPK LPJ Bali. Dokumentasi digunakan untuk memperoleh data berupa foto kegiatan pembelajaran dan media pembelajaran. Berdasarkan hasil observasi, wawancara, dan dokumentasi diperoleh hasil terkait strategi pembelajaran Kanji, faktor-faktor pemilihan strategi pembelajaran Kanji, dan hambatan dalam pembelajaran Kanji. Strategi pembelajaran digunakan oleh guru mata pelajaran Kanji di LPK LPJ Bali untuk membantu siswa memahami dengan mudah materi pembelajaran yang diberikan. Strategi yang digunakan guru dalam pembelajaran, yaitu. 


\section{Strategi Drill}

Perbedaan penyajian drill tetap mengutamakan ketangkasan siswa dalam merespon stimulus yang diberikan oleh guru. Jenis strategi drill yang sering digunakan guru pengajar Kanji di LPK LPJ Bali yaitu repetition drill dan question and answer drill question and answer drill.

Repetition drill digunakan untuk melatih pelafalan kosa kata bagi siswa. Siswa yang kesulitan dalam melafalkan kosa kata diminta mengikuti pelafalan guru. Dengan demikian, siswa dapat melafalkan kosa kata dengan lebih baik, misalnya kata fukuzatsu (rumit) Hal tersebut disebabkan karena, strategi ini menciptakan latihan berulang-ulang pada siswa untuk mengingat Kanji dan kosa kata.

Guru juga menggunakan question and answer drill dengan menggunakan media kartu kosa kata. Perbedaan teknik drill ini, yaitu siswa tidak mengulang kosa kata yang diucapkan guru melainkan menjawab pertanyaan guru mengenai cara baca dan arti kosa kata. Sebelum didrill secara individual, guru melakukan drill berkelompok terlebih dahulu. Strategi ini tidak hanya digunakan untuk melatih materi baru melainkan juga saat melatih siswa dalam pengulangan materi yang sudah pernah dipelajari. Siswa akan diperlihatkan kosa kata tertentu yang sudah diacak kemudian diminta menjawab dengan cepat dan tepat mengenai cara baca dan arti kosa kata yang diperlihatkan. Hal ini berguna untuk melatih siswa dalam menghafalkan Kanji .

Guru : (Guru memperlihatkan kartu kosa kata)

Siswa : "Osu, menekan"

Tujuan penggunaan strategi question and answer drill dan repetition drill, yakni untuk memberikan keterampilan dalam menghapalkan Kanji dan kosa kata serta mendorong daya ingatan yang semakin baik terhadap materi yang disampaikan. Selain itu, strategi ini juga bertujuan agar siswa dapat menggunakan daya pikirnya yang semakin lama semakin baik karena dengan pengajaran yang baik maka peserta didik akan menjadi lebih teratur dan lebih teliti dalam mendorong ingatannya.

Penggunaan strategi question and answer dapat sebagai kegiatan konfirmasi atas pemahaman siswa terhadap materi yang sudah disampaikan. Setelah membahas materi secara keseluruhan, guru melakukan question and answer untuk mengetahui sejauh mana pemahaman siswa terhadap materi tersebut. Siswa yang kesulitan dalam menghafalkan Kanji maupun kosa kata akan dilatih secara berulang. Selain itu, question and answer dilakukan untuk mengetahui kesiapan siswa sebelum mengikuti tes kecil. Dengan menggunakan strategi ini, siswa dapat lebih mudah dalam mengingat materi pembelajaran Kanji .

\section{Strategi Ekspositori}

Strategi pembelajaran ekspositori adalah strategi pembelajaran yang memadukan strategi ceramah, tanya jawab dan peragaan demonstrasi (Sanjaya 2016). Guru melakukan tanya jawab kepada siswa terkait cara baca, arti Kanji dan jumlah goresan. Strategi tanya jawab juga digunakan ketika guru ingin melakukan konfirmasi terhadap informasi yang dimiliki siswa mengenai materi yang dibahas.

Berikut ini contoh tanya jawab yang dilakukan oleh guru, di antaranya.

Guru : "Taifuu no imi wa nan desuka? (apakah arti taifuu ?)"

Siswa : "Angin topan"

Guru : "Seikai. Angin topan desune. Taifuu wo tsukatta bun wo kangaetemite kudasai. Dekitara, te wo agete kudasai ! (benar. Angin topan, ya. Silakan pikirkan kalimat yang menggunakan kosa kata taifuu)"

Siswa : "Kinou wa taifuu ga fukimashita (kemarin bertiup angina topan)

Guru : "Subarashii. Kinou wa taifuu ga fukimashita. Seikai desu (bagus sekali. kemarin bertiup angina topan. Itu benar)".

Selain tanya jawab, guru juga melakukan variasi dengan ceramah apabila terdapat kosa kata yang tidak dipahami siswa. Selain itu, guru juga selalu melakukan demonstrasi terkait penulisan huruf Kanji dengan menulis huruf di udara. Siswa diajak menulis di udara bersama-sama untuk memahami urutan penulisan Kanji. Dengan memahami urutan 
penulisan yang benar, siswa diharapkan mampu mengingat penulisan huruf Kanji. Demonstrasi tersebut membantu siswa membayangkan bentuk huruf Kanji.

Langkah-langkah dalam penerapan strategi ekspositori dalam pembelajaran Kanji, yaitu (1) Persiapan (Preparation), yaitu tahap mempersiapkan siswa menerima pembelajaran. Pada tahap persiapan, guru melakukan tanya jawab seperti, apakah siswa sudah mempelajari materi yang sebelumnya atau belum. Guru juga melakukan tanya jawab terkait kosa kata dan Kanji yang sudah dipelajari sebelumnya untuk mengetahui sejauh mana siswa sudah belajar. Selain itu, guru juga menggunakan question and answer drill sebagai latihan pengulangan materi yang sudah dipelajari pada pertemuan sebelumnya. Hal tersebut juga sebagai upaya mempersiapkan siswa sebelum mengikuti tes kecil; (2) Penyajian (Presentation), penyajian materi pembelajaran oleh guru. Guru melakukan presentasi terkait materi baru dengan menggunakan power point maupun menulis huruf di papan tulis lengkap dengan tanda urutan penulisannya. Dalam menyajikan materi, guru lebih banyak melakukan tanya jawab kepada siswa; (3) Korelasi ( Correlation), yaitu langkah menghubungkan materi pelajaran dengan pengetahuan atau pengalaman yang dimiliki siswa. Misalnya dalam menjelaskan materi Kanji mengenai empat musim di Jepang, yaitu natsu (musim panas), aki ( musim gugur), fuyu (musim dingin) dan haru (musim semi). Guru menjelaskan Kanji tersebut dengan menghubungkan pada pengetahuan siswa mengenai musim di Jepang. Mengingat, ilusrasi tersebut dapat berkaitan dengan bentuk Kanji; (4) Menyimpulkan (Generalization), yaitu tahapan untuk memahami inti dari materi pelajaran yang sudah dilakukan. Menyimpulkan bisa dilakukan dengan beberapa cara, di antaranya pertama, dengan cara mengulang kembali inti-inti materi yang menjadi pokok persoalan. Kedua, dengan cara memberikan beberapa pertanyaan yang relevan dengan materi yang telah disajikan. Ketiga, dengan cara maping melalui pemetaan keterkaitan antarmateri pokok- pokok materi. Pada langkah ini, guru melakukan beberapa variasi, seperti dengan melakukan tanya jawab kepada siswa, meminta siswa menjawab soal kuis, serta membahas kembali kosa kata yang sulit dijawab siswa saat permainan; (5) Mengaplikasikan (Aplication), yaitu tahap dimana guru dapat mengumpulkan informasi tentang penguasaan dan pemahaman materi pelajaran oleh siswa. Teknik yang biasa dilakukan dalam langkah ini, di antaranya pertama, dengan membuat tugas yang relevan dengan materi materi yang telah disajikan. Kedua, dengan memberikan tes yang sesuai dengan materi pelajaran yang sudah disampaikan. Guru memberikan tes kecil kepada siswa terkait materi yang sudah diajarkan untuk mengetahui sejauh mana siswa mampu menguasai Kanji yang sudah dipelajari. Tes kecil tersebut tidak dilaksanakan pada akhir pembelajaran, melainkan pada awal pembelajaran pertemuan berikutnya. Sebab, berdasarkan keterangan guru bahwa waktu selama pembelajaran lebih dimanfaatkan untuk memberikan latihan yang optimal kepada siswa. Mengingat, materi Kanji yang diberikan cukup sulit bagi siswa. Sehingga, siswa diberikan kesempatan untuk mempejalari kembali di rumah. Hal ini juga sebagai cara agar siswa dapat belajar secara intensif setelah pembelajaran di kelas berakhir.

Berdasarkan pemaparan tersebut dapat disimpulkan penggunaan strategi ekspositori merupakan variasi dari strategi ceramah, tanya jawab dan demonstrasi. Terdapat beberapa tahapan dalam strategi ini, yaitu tahap pesiapan, penyampaian materi, korelasi, menyimpulkan dan mengaplikasikan. Strategi ini sangat efektif dalam pembelajaran Kanji karena menekankan pada proses pemberian pengetahuan, latihan-latihan, hingga penerapan. Sehingga kemampuan siswa tidak hanya terbatas pada pengetahuan saja. Kelima tahap tersebut saling berkaitan sehingga tujuan pembelajaran dapat tercapai.

\section{Strategi Permainan}

Strategi permainan tidak hanya efektif dalam pembelajaran anak-anak melainkan juga pada tingkat yang lebih tinggi. Dalam penerapan strategi ini, guru perlu memilih permainan yang tepat sesuai dengan materi pembelajaran. Strategi permainan yang digunakan dalam pembelajaran Kanji di kelas N4 Keperawatan, hampir mirip dengan repetition drill. Namun, terdapat variasi dalam pelaksanaannya. Guru menetapkan aturan berupa waktu, poin dan tata tertib siswa. Permainan ini dipilih karena sesuai dengan 
materi yang diajarkan serta target yang ingin dicapai. Siswa dituntut untuk berpikir cepat dan terpacu untuk menghafalkan Kanji yang dibahas.

Selain permainan yang mirip repetition drill berkelompok dengan bantuan media kartu kosa kata. Guru juga menggunakan permainan menemukan kosa kata pada Kanji yang di tampilkan di Power Point serta menyusun potongan Kanji menjadi kosa kata. Hal ini menuntut kemampuan siswa dalam mengingat kosa kata beserta cara baca dan artinya. Guru juga menggunakan permainan berkelompok menulis Kanji. Hal tersebut sebagai latihan menulis bagi siswa untuk mampu mengingat Kanji.

Permainan mirip drill divariasikan oleh guru dengan tujuan agar pelaksanaan permainan tidak monoton. Variasi tersbeut dapat berupa jumlah siswa dalam kelompok, perolehan poin dan aturan pelaksaan permainan. Dengan kegiatan permainan, siswa menjadi antusias dalam pembelajaran karena tidak hanya duduk di bangku dan mendengarkan penjelasan materi. Melainkan, dapat berinteraksi dengan teman, melakukan aktivitas fisik namun tetap relevan dengan materi pelajaran. Selain itu, perolehan poin membuat siswa termotivasi untuk berusaha menghafalkan kosa kata serta penulisannya dengan baik. Dalam kegiatan permainan, siswa juga selalu diberikan semangat oleh guru.

\section{Strategi Pemberian Tugas}

Dalam pembelajaran Kanji guru sering memberikan tugas kepada siswa untuk secara mandiri melanjutkan menulis Kanji pada kertas genkouyoushi atau kertas latihan menulis huruf Jepang. Selain itu, siswa juga diberikan tugas untuk mempelajari materi pada pertemuan selanjutnya. Siswa dapat secara mandiri mencari tahu arti kosa kata yang muncul pada Kanji. Pemberian bertujuan untuk mengetahui atau mengukur hasil belajar siswa. Jangka waktu pengerjaan tugas tersebut, yaitu selama satu minggu. Tugas diberikan rutin setiap akhir pembelajaran. Tugas tersebut diserahkan kepada guru pada pertemuan berikutnya. Guru selalu melakukan evaluasi terhadap tugas siswa. Evaluasi dilakukan berdasarkan, ketepatan jumlah goresan, dan keseimbangan bentuk Kanji, serta kerapian penulisan huruf secara keseluruhan. Tugas tersebut dikerjakan setelah pembelajaran berakhir. Dengan demikian, siswa dapat mengerjakan tugas di asrama. Tugas dapat dikerjakan secara individu maupun berkelompok.

Selain itu pemberian tugas berupa menulis huruf Kanji dan mencari arti kosa kata, guru juga memberikan tugas siswa untuk menjawab soal - soal moji goi pada kumpulan soal nouryokushiken. Keterangan ini berdasarkan hasil wawancara dengan guru mata pelajaran Kanji. Soal-soal moji goi tersebut nantinya akan dibahas ketika materi pembelajaran sudah habis dibahas dalam pembelajaran. Pemberian tugas menjawab kumpulan soal moji goi merupakan persiapan siswa sebelum mengikuti tes kemampuan bahasa Jepang. Tugas yang diberikan dapat berupa soal-soal latihan atau soal lisan yang harus dikerjakan siswa di sekolah maupun di rumah. Dengan mengejarkan tugas, siswa dapat berlatih kembali di rumah mengenai materi yang sudah diajarkan. Pemberian tugas ini terbukti mampu meningkatkan hasil belajar siswa dalam menguasai Kanji. Siswa dapat belajar tidak hanya di dalam kelas namun juga di luar jam pembelajaran. Sehingga alokasi waktu selama tiga bulan dapat dimanfaatkan secara optimal.

Dalam memilih strategi pembelajaran guru mempertimbangkan faktor-faktor pemilihan strategi. fBerikut ini faktor-faktor pemilihan strategi pembelajaran Kanji di LPK LPJ Bali, yaitu.

\section{Karakteristik Peserta Didik}

Pemilihan strategi pembelajaran Kanji di kelas N4 Keperawatan berkaitan dengan karakteristik peserta didik. Siswa di LPK LPJ Bali mempunyai rentang usia dari 19 sampai 29 tahun. Siswa pada rentang usia remaja tentu memiliki mental dan kecakapan intelektual yang berbeda. Meskipun demikian, rentang usia tersebut dapat menerima strategi apapun. Siswa pada rentang usia ini bukan lagi anak kecil sehingga dapat tertib mengikuti aturan. Siswa dapat dikendalikan khususnya ketika pelaksanaan strategi permainan. Sehingga, kegiatan pembelajaran tidak mengganggu kelas lain. Siswa juga mengikuti aturan yang 
diberikan oleh guru. Meskipun pembelajar pemula siswa mampu memahami dan merespon penjelasan sederhana yang diberikan guru.

Siswa juga sudah matang secara psikomotor, yakni mampu melakukan aktivitas yang berkaitan dengan fisik. Sehingga, guru melakukan variasi pembelajaran dengan menggunakan strategi permainan tebak kosa kata dalam kelompok. Siswa dapat berinteraksi dengan teman, melakukan gerakan, sehingga tidak terpaku hanya duduk di bangku. Aktivitas gerak tersebut berguna bagi kesehatan fisik siswa dalam pembelajaran selama 3-4 jam. Otot digerakkan sehingga menjadi tidak kaku. Siswa dapat mengikuti pembelajaran dengan baik dan antusias.

Siswa perawat merupakan pembelajar pemula. Hal tersebut karena siswa belum pernah memperlajari bahasa Jepang, khususnya Kanji. Siswa merasa kesulitan karena tidak terbiasa membaca dan menulis Kanji. Oleh karena itu, guru melakukan beberapa strategi pembelajaran seperti repetition drill untuk memberikan latihan berulang-ulang. Strategi ini digunakan ketika pengulangan (fukushuu), dalam inti pembelajaran, dan akhir pembelajaran. Selain itu, pada strategi ekspositori, guru memberikan pengetahuan dan latihan menulis Kanji. Siswa sebagai pembelajar pemula, kesulitan dalam memahami Kanji yang rumit sehingga digunakan strategi tanya jawab. Dalam strategi tersebut siswa dapat bertanya hal yang kurang dipahami begitu sebaliknya guru dapat bertanya untuk memastikan pemahaman siswa.

\section{Kompetensi Dasar yang Diharapkan}

Kompetensi dasar yang diharapkan, yaitu siswa mampu membaca dan menulis Kanji pada level N4. Selain membaca, siswa juga harus mengetahui arti Kanji dan kosa kata yang muncul sebagai persiapan menghadapi tes kemampuan bahasa Jepang. Dalam tes yang berisikan soal kosa kata (moji goi), tata bahasa (bunpou) dan membaca (dokkai), siswa tidak hanya dituntut mampu membaca hiragana dan katakana melainkan juga Kanji. Jumlah Kanji yang harus dikuasai siswa yaitu 300 kanji.

Kosa kata yang keluar pada Kanji level N4 meliputi kosa kata yang sering digunakan saat tinggal di Jepang, yang terdiri atas kata kerja, kata sifat, kata benda dan lain-lain. Banyak aturan dan larangan di Jepang yang ditulis dengan Kanji. Informasi di daerah tersebut juga sebagai besar menggunakan Kanji. Sehingga, kompetensi membaca dan mampu memahami Kanji sangat penting agar siswa tidak terlalu merasa kesulitan ketika hidup di Jepang. Selain itu, dengan bekal pengetahuan kosa kata, siswa dapat menggunakannya dalam komunikasi. Sehingga, tahap pengetahuan Kanji dan kosa kata merupakan tahap awal yang harus dimiliki siswa. Siswa perawat juga akan dihadapkan pada administrasi di Jepang sehingga mereka harus mampu menulis Kanji khususnya Kanji level N4. Berdasarkan kompetensi tersebut guru memilih strategi repetition drill, ekspositori dan permainan. Selain itu, guru juga memberikan tugas agar siswa dapat tetap berlatih ketika pembelajaran sudah berakhir. Strategi tersebut sangat efektif dalam mencapai kompetensi dasar yang diharapkan. Terbukti, siswa mampu menjawab soal-soal latihan $\mathrm{N} 4$, mampu lulus NAT-Test dan J-Test.

\section{Waktu yang Tersedia}

Demikian halnya dengan kegiatan pembelajaran di kelas N4 LPK LPJ Bali yang mana strategi yang digunakan berdasarkan atas waktu yang tersedia. Pembelajaran Kanji di kelas ini berlangsung selama 3 bulan. Guru yang sudah berkoordinasi dengan tim pengajar mengenai batas materi yang diberikan, harus mampu mencapai menyampaikan materi hingga mencapai sasaran. Oleh karena itu, guna memaksimalkan perkembangan dan hasil belajar siswa selama 3 bulan, guru melakukan variasi strategi seperti drill, ekspositori, permainan, pemberian tugas. Berdasarkan hasil wawancara dengan guru, alokasi waktu selama 3 bulan menuntut pengajar untuk memilih strategi pembelajaran yang tepat untuk membantu siswa dalam belajar secara efektif dan intensif.

Berdasarkan hasil observasi dan wawancara, terdapat beberapa hambatan dalam pembelajaran Kanji di kelas N4 Keperawatan LPK LPJ Bali, yaitu. 


\section{Hambatan Manusiawi}

Hambatan manusiawi yang dihadapi guru, yaitu tidak semua siswa dapat mengikuti pembelajaran hingga berakhir. Hal tersebut disebabkan karena empat orang siswa di dalam kelas memiliki tugas piket secara bergiliran untuk menyiapkan makan siang dan makan malam. Sehingga, satu jam sebelum pembelajaran berakhir, siswa yang piket harus meninggalkan kelas. Siswa menjadi tidak dapat mengikuti akhir pembelajaran, seperti permainan dan tanya jawab materi yang sulit. Guru mengatasi hal tersebut dengan melakukan drill kepada siswa yang piket pada pertemuan selanjutnya.

\section{Hambatan Institusional}

Hambatan institusional dialami karena posisi kelas yang di samping dapur Sehingga saat siswa piket menyiapkan makan siang, suara dari dapur tersebut cukup terdengar sampai ke ruang kelas. Guru mengatasi hal tersebut dengan mengarahkan siswa yang piket untuk tidak ribut saat sedang memasak. Selain itu, aroma masakan dari dapur mempengaruhi kosentrasi belajar siswa. Siswa menjadi mudah lapar karena mencium aroma masakan. Mengingat, bagian belakang dapur yang langsung terhubung dengan bagian depan kelas tanpa adanya pintu atau pembatas. Guru mengatasi hal tersebut dengan mengarahkan siswa untuk membuka ventilasi sehingga memungkinkan adanya sirkulasi udara.

\section{Hambatan Instruksional}

Hambatan instruksional, yaitu hambatan yang dalam hal alat peraga, media pembelajaran dan lain-lain. Salah satu hambatan sarana pembelajaran yaitu, tidak tersedianya LCD maupun TV di kelas N4 B Keperawatan sehingga guru tidak bisa menyajikan materi berupa power point. Berbeda halnya dengan kelas N4 A Keperawatan yang dilengkapi dengan fasilitas seperti LCD untuk menampilkan power point. Sehingga, guru menyajikan materi dengan bantuan kotoba kaado atau kartu kosa kata serta menulis huruf Kanji di papan tulis disertai dengan urutan penulisan yang ditandai dengan angka. Dengan demikian kegiatan pembelajaran tetap berjalan dengan baik.

Selain itu, tidak tersedianya LCD membuat beberapa permainan di kelas A tidak dapat dilaksanakan di kelas $\mathrm{B}$, misalnya permainan mencari kosa kata pada Kanji-Kanji yang ditampilkan pada layar LCD serta kuis setelah membahas materi yang biasanya ditampilkan melalui LCD. Guru mengatasi hal tersebut dengan membuat potongan-potongan Kanji yang dapat disusun secara langsung menjadi kosa kata oleh siswa. Soal-soal kuis yang diberikan di kelas N4 A menjadi bahan tanya jawab untuk siswa di kelas N4 B. Hal tersebut mampu mengatasi kendala fasilias LCD yang dihadapi.

Selain itu, media kartu Kanji yang terbatas yaitu hanya satu paket untuk satu bab Kanji. Masing-masing siswa tidak dapat menggunakan media tersebut secara pribadi dalam pembelajaran. Namun, guru mengatasinya, dengan membentuk kelompok saat permainan, sehingga seluruh siswa dapat memanfaatkan media secara optimal.

\section{Simpulan dan Saran}

Berdasarkan hasil penelitian dan pembahasan mengenai profil strategi pembelajaran Kanji di kelas N4 Keperawatan LPK LPJ Bali, dapat disimpulkan sebagai berikut. (1) Strategi pembelajaran Kanji yang digunakan oleh guru di kelas N4 Keperawatan LPK LPJ Bali yaitu, strategi drill, ekspositori, permainan yang dilaksanakan di dalam kelas serta strategi pemberian tugas yang dilakukan ketika kegiatan pembelajaran sudah berakhir. (2) Faktor-faktor pemilihan strategi pembelajaran, yaitu karakteristik peserta didik, kompetensi dasar yang diharapkan dan waktu yang tersedia dalam pembelajaran Kanji. Sehingga target pembelajaran dapat tercapai dengan maksimal. (3) Hambatan yang dihadapi dalam pembelajaran Kanji yaitu, dari faktor manusiawi, institusional dan instruksional.

Berdasarkan temuan selama penelitian ini, maka dapat disampaikan beberapa saran, yaitu sebagai berikut. (1) Guru mata pelajaran Kanji di kelas N4 Keperawatan LPK LPJ Bali hendaknya menyiapkan RPP ( Rencana Pelaksanaan Pembelajaran) dan 
silabus sebagai acuan dalam mengajar Kanji. (2) Guru mata pelajaran Kanji di kelas N4 Keperawatan LPK LPJ Bali hendaknya juga melakukan pembahasan Kanji-Kanji dan kosa kata yang berkaitan dengan profesi keperawatan. (3) Perlu diadakan penelitian pembuatan produk yang berkaitan dengan RPP (Rencana Pelaksanaan Pembelajaran) dan silabus terkait pembelajaran Kanji untuk lulus tes bahasa Jepang level 4.

\section{Daftar Pustaka}

Benati, Alessandro. 2018. "Grammar-Translation Method". Tersedia pada https://booksc.xyz/book/68323580/e392a7 (diakses tanggal 14 Juni 2020)

Febriyanti, Rina H. 2017. "Penggunaan Metode Communicative Language Teaching Dalam Pengajaran Bahasa Inggris Pada Guru Tutor Di Bimbingan Belajar". Tersedia pada https://journal.Ippmunindra.ac.id/index.php/Faktor/article/view/2029/1580 (diakses tanggal 26 Mei 2020 )

Gracia, Nowelia Malia. 2018. The Tesol Encyyclopedia of English Language Teaching : Using Dialogues, Role Plays, Songs, and Poetry in Teaching Speaking. doi : 10.1002/9781118784235.eelt0259

Hamalik, Oemar. 2002. Perencanaan Pengajarn Berdasarkan Pendekatan Sistem. PT Bumi Angkasa: Jakarta.

Kayi, Hayriye. 2006. "Teaching Speaking Activities to Promote Speaking in a Second Language" Tersedia pada http://iteslj.org/Techniques/Kayi-TeachingSpeaking.html (diakses tanggal 26 Mei 2020)

Padmadewi, Ni Nyoman. 2012. Strategi Pembelajaran. Singaraja: Undiksha Press.

Roestiyah. 2012. Strategi Belajar Mengajar. Jakarta: Rineka Cipta.

Samad, Farida dan Tidore, Nurlela. 2015. "Strategi Pembelajaran Bahasa Inggris Yang Menyenangkan Untuk Anak Usia Dini” Tersedia pada https://media.neliti.com/media/publications/296141-strategi-pembelajaran-bahasainggris-yan-5d89f42b.pdf (diakses tanggal 27 Mei 2020)

Sanjaya, Wina. 2016. Strategi Pembelajaran Berorientasi Standar Proses Pendidikan. Jakarta: Prenadamedia Group.

Sunendar, Dadang dan Iskandarwassid. 2015. Strategi Pembelajaran Bahasa. Bandung: PT Remaja Rosdakarya.

Tarigan, Henry Guntur. 2011. Pengajaran Analisis Kesalahan Berbahasa. Bandung. Angkasa.

Yani, Damai. 2016. "Metode Audiolingual Dalam Pembelajaran Kaiwa". Lingua Didaktika, Volume 10, Nomor 1, Juli 2016 (hml. 9-17). 